\title{
Identification key for the genera of Syrphidae (Diptera) from the Brazilian Amazon and new taxon records
}

\author{
Gil Felipe Gonçalves MIRANDA ${ }^{1^{*}}$ \\ 1 Instituto Nacional de Pesquisas da Amazônia, Coordenação de Biodiversidade. Avenida André Araujo, 2936, Bairro Petrópolis - Manaus, Amazonas, Brazil - CEP: 69060-060. \\ *Corresponding author: gilfgm@gmail.com.
}

\begin{abstract}
Identification keys are essential to properly recognize taxa, and a photographic key not only addresses that issue but can also attract the interest of the general public if designed correctly. Syrphidae is one of the largest families of Diptera, and the Brazilian Amazon holds more taxon records from this family than currently reported. The aim of the current study was to provide an updated photographic identification key, of easy use and access, to the genera of Syrphidae (Diptera) from the Brazilian Amazon region, and identify previously unrecorded taxa. Through a literature review and study of collection material from several institutions, I found 36 new taxon records for the Brazilian Amazon (15 are first records for Brazil) and provided a list of references with identification keys to species from each genus. The online version of this manuscript has a photographic identification key, with diagnostic pages for each genus, as supplementary material.
\end{abstract}

KEYWORDS: Flower fly; live pictures; Neotropical; online; taxonomy

\section{Chave de identificação para os gêneros de Syrphidae (Diptera) da Amazônia brasileira e novos registros}

\section{RESUMO}

Chaves de identificação são essenciais para reconhecer táxons, e uma chave pictórica atende a essa demanda e também desperta o interesse do público em geral, se for desenhada apropriadamente. Syrphidae é uma das maiores famílias de Diptera, e a Amazônia brasileira possui mais táxons dessa família do que registrado atualmente. O objetivo deste estudo foi prover uma chave de identificação pictórica atualizada, de fácil uso e acesso, para os gêneros de Syrphidae (Diptera) da Amazônia brasileira, e identificar táxons ainda não registrados. Através de uma revisão da literatura e estudo de material de diversas coleções, eu encontrei 36 novas ocorrências de táxons para a Amazônia brasileira (15 sendo primeiros registros para o Brasil) e disponibilizei uma lista de referências com chaves de identificação para as espécies de cada gênero. A versão online desse manuscrito possui uma chave de identificação pictórica como material suplementar.

PALAVRAS-CHAVE: Fotos; mosca das flores; Neotropical; online; taxonomia 


\section{INTRODUCTION}

The general public wants to know more about natural environments and the organisms that live there (Quaresma 2003). Biodiversity professionals need to identify the groups that occur in the different biomes. An identification key that is updated and easy to use meets the demands of both the general and scientific audiences.

The Amazonian region holds a highly diverse fauna and flora (Hoorn and Wesselingh 2010). Large animals such as mammals (Sigrist 2012) and more conspicuous plants such as orchids (Luz and Oliveira 2012) are usually highlighted in Amazonian literature. Insects are mostly seen as a nuisance and/or risk (e.g. mosquitoes), with most people unaware of their great diversity (Rafael et al. 2009).

Syrphids, also known as flower/hover flies (Diptera: Syrphidae), are an example of poorly studied fauna in the Brazilian Amazon. The diversity of syrphid forms reaches extremes where they can be mistaken for wasps and bees (Hymenoptera) (Thompson et al. 2010). Most adults feed on nectar and pollen, with the larvae having habits and habitats much more diverse than the adults (Rotheray and Gilbert 1999; Pérez-Lachaud et al. 2014). The family is currently divided into four subfamilies: Eristalinae (mainly saprophagous larvae), Microdontinae (larvae that scavenge in ant nests), Pipizinae and Syrphinae (mainly predaceous larvae) (Thompson et al. 2010; Mengual et al. 2015). In Europe there is a long tradition in the study of syrphids, not only in academia (Bartsch 2009a; 2009b), but also with many amateurs/enthusiasts providing useful information on these flies (e.g. Owen 2010; Ball and Morris 2013). This encourages 'citizen-scientists' to develop an interest in the biodiversity around them, which can also aid on gathering data for ecological studies (Dickinson et al. 2010). The Amazon syrphid fauna could be explored in the same way as was done in Europe and in the Nearctic (Miranda et al. 2013). Thus, the objective of the current study is to develop a photographic identification key, as supplementary material, to the genera of Syrphidae from the Brazilian Amazon and present new records of distribution.

\section{MATERIALS AND METHODS}

\section{Specimens and area studied}

Material studied came from the following Brazilian institutions: Coleção de Invertebrados from the Instituto Nacional de Pesquisas da Amazônia (INPA)-Manaus/AM, Coleção Zoológica do Maranhão (CZMA)-Caxias/MA, Museu Nacional da Universidade Federal do Rio de Janeiro (MNRJ)-Rio de Janeiro/RJ and Museu Paraense Emílio Goeldi (MPEG)-Belém/PA. All voucher material remained at the institutions mentioned above. Terminology followed
Thompson (1999) and Cumming and Wood (2009), with some terms simplified to ease understanding by the user (e.g. 'antennal base' instead of 'frontal prominence' or 'antennifer'). Some common terms for structures on syrphids (e.g. venation) and notes on orientation (e.g. anterior x posterior) can be found only in the supplementary material online.

The genera presented in this key were taken from the literature (Thompson et al. 1976; Thompson 1999; Reemer and Ståhls 2013a, 2013b) and later supplemented with new taxon records found in the material studied. Generic classification followed updated Neotropical Syrphidae literature (e.g. Miranda 2011; Reemer e Ståhls 2013a; 2013b; Miranda et al. 2014). Species lists were based in the literature (Thompson et al. 1976; Rotheray et al. 2000; Blatch et al. 2003; Borges and Pamplona 2003; Rotheray et al. 2007; Thompson 2007a, b; Mengual and Thompson 2008; Borges and Couri 2009; Mengual et al. 2009; Morales and Marinoni 2009; Reemer 2010; Thompson 2010; Miranda 2011; Montoya et al. 2012; Reemer 2012; Ricarte et al. 2012; Reemer and Ståhls 2013a; Miranda 2014; Miranda et al. 2014; Reemer 2014).

The study area was limited to the Brazilian Amazon, but took into consideration records for the Amazon of neighbouring countries (Bolivia, Colombia, French Guyana, Guyana, Peru, Surinam and Venezuela) since the taxa could occur in the Brazilian side as well. The 'Brazilian Amazon' considered in this study represents the 'Amazônia legal' (see figure 1 in Fearnside 2014), but limited to the rainforest areas (Acre, Amazonas, Amapá, western Maranhão, northern Mato Grosso, Pará, Rondônia, Roraima and northern Tocantins).

For records that indicated only Maranhão, Mato Grosso or Tocantins, without indicating where in those states, they were only considered part of the Brazilian Amazon if they had records in other Amazonian areas (e.g.: for a record indicating 'Mato Grosso, Venezuela' it was assumed that the species was part of the Amazonian part of Mato Grosso). Species records from the literature that indicated only 'Brazil' were not considered.

For cases where the species was assumed to occur in the Brazilian Amazon, the species name was followed by an asterisk $\left(^{*}\right)$ and either a neighbouring country name or 'Amazon'. A country name was used when the record was in an Amazonian region in that neighbouring country. 'Amazon' was used when the record in the literature only mentioned 'Amazon' or 'Amazon valley'.

New records found in the material studied were indicated after the species name by 'n. rec.' followed by 'BR', if they were new records for Brazil, and/or the acronym for the state (in bold) if it was a new record for that state, i.e.: AC-Acre, AMAmazonas, AP-Amapá, MA-Maranhão, MT-Mato Grosso, PA-Pará, RO-Rondônia, RR-Roraima, and TO-Tocantins. 


\section{Images and key development}

Most images were obtained by the author using a camera set on a stereomicroscope (M205, Leica, Wetzlar, Germany), and the software Leica Application Suite (v.3.6, Leica, Wetzlar, Germany), in the Laboratório de Entomologia Sistemática, Urbana e Forense (LESUF/CBio/INPA), or in the field with a DSLR camera (D3100, Nikon, Tokio, Japan) and macro lens (Macro 105mm/f2.8, Nikon, Tokio, Japan). Some images were obtained from other sources, which were indicated in the corner of the images. Images were edited in the Adobe Photoshop software (CS4, Adobe, San Jose, USA).

The steps of the key were made in the Adobe Illustrator software (CS4, Adobe, San Jose, USA) and exported as hypertext pages (HTML). The format of the key followed Miranda et al. (2013), with steps leading to a diagnostic taxon page or to another step. There are two types of steps: (1) Multi-optional, where the user is shown several options of different character combinations that represent a group of taxa or a specific taxon; and (2) dichotomous, where there are only two options, of character combinations, to choose from. There may be links to species lists and additional images in the diagnostic taxon pages. Some taxa occurred more than once in the key due to the diversity of forms and intermediate cases that they possess.

Some images in the key had highlighted structures, that appeared in either of two ways: (1) a red frame highlighting the position of the structure on the specimen followed by another image on the side with the structure magnified and with a red border; or (2) an orange frame, highlighting the position of the structure on the specimen, which can be clicked to reveal a magnified view of the structure.

The PDF version was assembled from the individual HTML files through the 'Create PDF' (File/Create PDF/ From Web Page...) tool from the Adobe Acrobat software (9 Pro, Adobe, San Jose, USA) by selecting the first step of the key and adjusting the 'Capture multiple levels' settings to 'Get the entire site'.

\section{RESULTS}

This study reports 64 taxa (61 genera and three subgenera) for the Brazilian Amazon region, and 36 were new records for Brazil and/or the Brazilian Amazon region (Table 1 and Appendix 1).

The most recent keys for identification of species, updated from Thompson (1999), are listed on Tables 2, 3 and 4 . The key (online version and a "supplementary material" PDF version), instructions about orientation, and basic terminology can be accessed through the website http://keys.inpa.gov.br/?idkey=syrphidae.

The study of Reemer (2010) found a specimen of Paragus (Pandasyophthalmus) cf. haemorrhous in Surinam. The genus is present in North America, extending south at most into Costa
Table 1. New records of Syrphidae (Diptera) from the Brazilian Amazon. AC: Acre; AM: Amazonas; MA: Maranhão; PA: Pará; RR: Roraima.

\begin{tabular}{|c|c|c|}
\hline Species & $\begin{array}{l}\text { New Brazilian } \\
\text { record }\end{array}$ & $\begin{array}{l}\text { New state } \\
\text { record }\end{array}$ \\
\hline \multicolumn{3}{|l|}{ Eristalinae } \\
\hline Cepa margarita (Thompson, 1999) & $\checkmark$ & AM \\
\hline Mallota sp. & $\checkmark$ & AM \\
\hline Meromacrus milesia Hull, 1942 & $\checkmark$ & AM \\
\hline M. pachypus (Wiedemann, 1830) & & AM \\
\hline $\begin{array}{l}\text { Nausigaster bonariensis Lynch- } \\
\text { Arribalzaga, } 1892\end{array}$ & & PA \\
\hline Orthonevra sp. & & AM, MA \\
\hline Palpada aemula (Williston, 1891) & $\checkmark$ & PA \\
\hline P. agrorum (Fabricius, 1787) & & AM \\
\hline P. fasciata (Wiedemann, 1819) & $\checkmark$ & $\mathrm{AM}, \mathrm{PA}$ \\
\hline Polybiomyia bigotii (Williston, 1888) & & $\mathrm{RR}$ \\
\hline $\begin{array}{l}\text { Quichuana longicauda Ricarte \& Hancock, } \\
2012\end{array}$ & $\checkmark$ & AM \\
\hline \multicolumn{3}{|l|}{ Microdontinae } \\
\hline Aristosyrphus (Aristosyrphus) sp. & & AM \\
\hline Carreramyia sp. & $\checkmark$ & AM \\
\hline Ceratophya carinifacies (Curran, 1934) & & MA \\
\hline Domodon zodiacus Reemer, 2013 & $\checkmark$ & AM \\
\hline Hypselosyrphus trigonus Hull, 1937 & & AM \\
\hline Masarygus planifrons Brèthes, 1908 & & $\mathrm{PA}$ \\
\hline Menidon falcatus (Williston, 1887) & & AM \\
\hline $\begin{array}{l}\text { Microdon macquartii Lynch-Arribalzaga, } \\
1891\end{array}$ & $\checkmark$ & AM \\
\hline $\begin{array}{l}\text { Pseudomicrodon polistoides Reemer, } \\
2013\end{array}$ & $\checkmark$ & AM \\
\hline P. smiti Reemer, 2013 & $\checkmark$ & AM \\
\hline $\begin{array}{l}\text { Schizoceratomyia barretoi Carrera, Lopes } \\
\text { \& Lane, } 1947\end{array}$ & & $\mathrm{PA}$ \\
\hline Stipomorpha apicula (Curran, 1930) & $\checkmark$ & AM \\
\hline S. goettei (Shannon, 1927) & & AM \\
\hline S. guianica (Curran, 1925) & & AM \\
\hline S. mackiei (Shannon, 1927) & & AM \\
\hline Surimyia minutula (Doesburg, 1966) & $\checkmark$ & AM \\
\hline \multicolumn{3}{|l|}{ Pipizinae } \\
\hline Trichopsomyia polita Williston, 1888 & & $\mathrm{RR}$ \\
\hline \multicolumn{3}{|l|}{ Syrphinae } \\
\hline Calostigma elnora Shannon, 1927 & $\checkmark$ & AM \\
\hline $\begin{array}{l}\text { Eosalpingogaster cochenillivora (Guérin- } \\
\text { Méneville, 1848) }\end{array}$ & & PA \\
\hline Hybobathus placivus (Williston, 1888) & & PA \\
\hline Ocyptamus icarus Reemer, 2010 & $\checkmark$ & $\mathrm{AC}$ \\
\hline 0. obliquus (Curran, 1941) & & AM \\
\hline O. prenes (Curran, 1930) & & AM \\
\hline Pelecinobaccha pandora (Hull, 1941) & & AC \\
\hline Xanthandrus plaumanni Fluke, 1937 & & $\mathrm{AM}, \mathrm{RR}$ \\
\hline Total: 36 taxa & & \\
\hline
\end{tabular}


Table 2. Available references with species keys for Eristalinae (Syrphidae) with records for the Brazilian Amazon.

\begin{tabular}{|c|c|}
\hline Genus & Reference \\
\hline \multicolumn{2}{|l|}{ Eristalinae } \\
\hline Alipumilio & Vockeroth (1964) \\
\hline Cepa & Thompson (2007a) \\
\hline Chalcosyrphus (Neplas) & $\begin{array}{c}\text { Curran (1941) (as Planes) and } \\
\text { Thompson (1981) }\end{array}$ \\
\hline Copestylum & $\begin{array}{l}\text { Curran }(1939,1953) \text { (as Volucella), } \\
\text { Fluke (1951) and Thompson (1981) }\end{array}$ \\
\hline Habromyia & Curran (1934) \\
\hline Lepidomyia & Hull (1946) (as Lepidostola) \\
\hline Lycastrirhyncha & Doesburg (1963) \\
\hline Mallota & Single species is illustrated in this study \\
\hline Meromacrus & $\begin{array}{l}\text { Hull (1942), Thompson (1981) and } \\
\text { Blatch et al. (2003) }\end{array}$ \\
\hline Monoceromyia & $\begin{array}{l}\text { Curran (1941) and Thompson (1981) } \\
\text { (as Ceriana) }\end{array}$ \\
\hline Myolepta & Thompson (1968) \\
\hline Nausigaster & $\begin{array}{l}\text { Curran (1941) and Carrera et al. (1947) } \\
\text { (species published post Curran (1941)) }\end{array}$ \\
\hline Ornidia & Carvalho-Filho and Esposito (2009) \\
\hline Orthonevra & Single species is illustrated in this study \\
\hline Palpada & $\begin{array}{l}\text { Lagrange (1992), Mengual and Thompson } \\
\text { (2008) and Morales and Marinoni (2009) }\end{array}$ \\
\hline Polybiomyia & Curran (1941) \\
\hline Quichuana & Ricarte et al. (2012) \\
\hline Rhingia & Fluke (1943) \\
\hline Senogaster & Single species is illustrated in this study \\
\hline Sphiximorpha & Curran (1941) \\
\hline $\begin{array}{l}\text { Sterphus } \\
\text { (Ceriogaster) }\end{array}$ & $\begin{array}{c}\text { Hippa and Thompson (1994) and Zumbado } \\
\text { and Thompson (1997) }\end{array}$ \\
\hline $\begin{array}{l}\text { Sterphus } \\
\text { (Crepidomyia) }\end{array}$ & $\begin{array}{c}\text { Hippa and Thompson (1994) and Zumbado } \\
\text { and Thompson (1997) }\end{array}$ \\
\hline
\end{tabular}

Table 3. Available references with species keys for Microdontinae (Syrphidae) with records for the Brazilian Amazon.

\begin{tabular}{|c|c|}
\hline Genus & Reference \\
\hline \multicolumn{2}{|l|}{ Microdontinae } \\
\hline $\begin{array}{l}\text { Aristosyrphus } \\
\text { (Aristosyrphus) }\end{array}$ & No available species key \\
\hline $\begin{array}{l}\text { Aristosyrphus } \\
\text { (Eurypterosyrphus) }\end{array}$ & No available species key \\
\hline Carreramyia & Reemer (2013) \\
\hline Ceratophya & Reemer (2013) \\
\hline Ceriomicrodon & Miranda (2014) \\
\hline Chrysidimyia & Reemer and Ståhls (2013a) \\
\hline Domodon & $\begin{array}{l}\text { Reemer and Ståhls (2013a) and Reemer (2014) } \\
\text { (no key, only original descriptions) }\end{array}$ \\
\hline Hypselosyrphus & Reemer (2013) \\
\hline Laetodon & Doesburg (1966) (as Microdon geijskesi) \\
\hline Masarygus & $\begin{array}{l}\text { Reemer and Ståhls (2013a) (see discussion about } \\
\text { the genus and the description of M. palmipalpus) }\end{array}$ \\
\hline Menidon & Thompson (2007b) and Reemer and Ståhls (2013a) \\
\hline $\begin{array}{l}\text { Microdon } \\
\text { (Chymophila) }\end{array}$ & Curran (1941) \\
\hline $\begin{array}{l}\text { Microdon } \\
\text { (Microdon) }\end{array}$ & Curran (1941) \\
\hline Mixogaster & Carrera and Lenko (1958) \\
\hline Peradon & Curran (1941) (as Microdon) \\
\hline Piruwa & Reemer and Ståhls (2013a) \\
\hline Pseudomicrodon & Curran (1941) (as Microdon) \\
\hline Rhoga & Reemer (2012) \\
\hline Rhopalosyrphus & Thompson (2012) \\
\hline Schizoceratomyia & Papavero (1962) (as Masarygus) \\
\hline Stipomorpha & Reemer (2013) \\
\hline Surimyia & Reemer (2008) \\
\hline Ubristes & Reemer (2013) \\
\hline
\end{tabular}

Rica in Central America. Due to the single record in Reemer (2010), and the absence of specimens in the collections studied, this genus is not considered to be established in the Amazonian region and was not included in the key. Microdon (Syrphipogon) was not included in the key due to lack of conclusive evidences that its distribution could range into the Amazonian region (records only for Costa Rica, Panama and one record in the state of Paraná, Brazil).

A specimen of Polybiomyia, with a complete post-metacoxal bridge, was identified as Cerioides bigotii (Williston, 1888) in Curran (1941) key. Thompson (2010) recognizes it as Sphiximorpha bigotii (Williston, 1888), but the condition of the post-metacoxal bridge does not agree with Sphiximorpha (where it should be incomplete), so it is here placed in Polybiomyia. 
Table 4. Available references with species keys for Pipizinae and Syrphinae (Syrphidae) with records for the Brazilian Amazon.

\begin{tabular}{|c|c|}
\hline Genus & Reference \\
\hline \multicolumn{2}{|l|}{ Pipizinae } \\
\hline Trichopsomyia & Fluke (1937) \\
\hline \multicolumn{2}{|l|}{ Syrphinae } \\
\hline Allograpta & Fluke (1942) and Thompson (1981) \\
\hline Argentinomyia & Fluke (1945) (as Rhysops) \\
\hline Atylobaccha & Miranda et al. (2014) \\
\hline Calostigma & Hull (1949) \\
\hline Eosalpingogaster & Mengual and Thompson (2011) \\
\hline Fazia & Fluke (1942) (as Epistrophe) \\
\hline Hermesomyia & Vockeroth (1969) and Rotheray et al. (2000) \\
\hline Hybobathus & $\begin{array}{l}\text { Hull (1949) (as Baccha) and Reemer (2010) (as } \\
\text { Ocyptamus) }\end{array}$ \\
\hline Leucopodella & Thompson (1981) and Carvalho (2011) \\
\hline Mimocalla & Thompson and Zumbado (2000) \\
\hline Ocyptamus & $\begin{array}{l}\text { Hull (1949) (as Baccha), Thompson (1981) and } \\
\text { Reemer (2010) }\end{array}$ \\
\hline Orphnabaccha & $\begin{array}{l}\text { There are no appropriate current keys that cover the } \\
\text { region }\end{array}$ \\
\hline Pelecinobaccha & Miranda et al. (2014) \\
\hline Pseudodoros & Kassebeer (2000) \\
\hline Relictanum & Miranda et al. (2014) \\
\hline Salpingogaster & Curran (1941) and Thompson (1981) \\
\hline Toxomerus & $\begin{array}{c}\text { Thompson (1981), Borges and Couri (2009) and } \\
\text { Mengual (2011) }\end{array}$ \\
\hline Xanthandrus & Borges and Pamplona (2003) \\
\hline
\end{tabular}

\section{DISCUSSION}

This study discovered new taxon records for the Brazilian fauna of Syrphidae (Table 1), which reflects how much the fauna of this country, and specially the Amazonian region, is still underestimated. As an example, Mallota was only known from high altitude rain forests in South America, but this study found specimens in one of the few high altitude spots in the Brazilian Amazon. Another example was Carreramyia, unknown for Brazil but found in two different localities of the Amazonian lowlands (North and South of the Amazonas river), being captured only in canopy traps. These previously unknown taxa found in the Brazilian Amazon demonstrate the need to further study and definitely preserve this region and its still unknown biodiversity.

The key presented here will ease identification of syrphid genera in the Brazilian Amazon, allowing for a quicker assessment of new generic records, and also serving as an initial framework for regional taxonomic revisions and ecological studies. The compilation of references (Tables 2, 3 and 4) will direct the user to the most current species keys, and allied to the updated species lists in each taxon page, will also aid in identifying undescribed species or new records for the Brazilian Amazon.

\section{CONCLUSIONS}

Thirty-six new records of species and genera of Syrphidae are found, demonstrating the still unknown biodiversity present in the Brazilian Amazon. Furthermore, this study provides an updated identification key, and list of references to species keys, providing an initial study framework that will aid in future ecological studies and taxonomical revisions.

\section{ACKNOWLEDGEMENTS}

I would like to thank Dr. José Albertino Rafael for logistic support during this study. Thanks also to the curators Dr. Francisco Limeira de Oliveira (CZMA), Dr. Márcio Oliveira (INPA), Dr. Cátia Mello-Patiu and Dr. Márcia Couri (MNRJ), and Dr. Orlando Tobias (MPEG), for loaning material. To colleagues Drs. Jeff Skevington, Menno Reemer, Steve Marshall and Ximo Mengual, and to the American Museum of Natural History, for sharing their pictures for use in the key. To Dr. Eduardo Abrantes for recovering label information. To colleagues at the LESUF/CBio/INPA, for comments and for testing the key online. To Thiago Andrade and Roberto Oliveira (CETIn/INPA) for hosting and maintaining the website. To INPA for the infrastructure. To the reviewers for the very helpful comments. To funding from FAPEAM/ PRONEX, 016/2006 (process 1437/2007), PRONEX PRJ 12.39, and FAPEAM 062.03129/2012 granted to LESUF/ INPA, and fellowships PDJ/CNPq (process 163108/2011-0) and PCI/INPA/CNPq (process 313083/2013-4) granted to the author.

\section{REFERENCES}

Ball, S.; Morris, R. 2013. Britain's Hoverflies: An introduction to the hoverflies of Britain. Princeton University Press, Princeton, 2013, 289 p.

Bartsch, H. 2009a. Diptera: Syrphidae: Syrphinae. Artdatabanken, Uppsala, 2009, 406 p.

Bartsch, H. 2009b. Diptera: Syrphidae: Eristalinae \& Microdontinae. Artdatabanken, Uppsala, 2009, 478 p.

Blatch, S.A.; Thompson, F.C.; Zumbado, M.A. 2003. A review of the Mesoamerican flower flies of the genus Meromacrus (Diptera: Syrphidae) including the description of a new species. Studia Dipterologica, 10: 13-36.

Borges, Z.M.; Pamplona, D.M. 2003. Revision of the neotropical Xanthandrus Verral (Diptera, Syrphidae). Revista Brasileira de Entomologia, 47: 155-167.

Borges, Z.M.; Couri, M.S. 2009. Revision of Toxomerus Macquart, 1855 (Diptera: Syrphidae) from Brazil with synonymic notes, identification key to the species and description of three new species. Zootaxa, 2179: 1-72.

Carrera, M.; Lopes, H.; Lane, J. 1947. Contribuição ao conhecimento dos "Microdontinae" neotrópicos e descrição de duas novas 
espécies de "Nausigaster" Williston (Diptera, Syrphidae). Revista Brasileira de Biologia, 7: 471-486.

Carrera, M.; Lenko, K. 1958. Descrição de duas espécies novas de Mixogaster (Diptera, Syrphidae) e observaçóes sôbre o inquilinismo de uma delas em ninhos de Iridomyrmex humilis, a "formiga argentina". Studia Entomologica, 1: 465-486.

Carvalho, A.H. 2011. Taxonomia do gênero neotropical Leucopodella Hull (Diptera: Syrphidae). Dissertação de Mestrado, Universidade Federal do Paraná, Curitiba, Paraná. 80 p.

Carvalho-Filho, F.S.; Esposito, M.C. 2009. A review of the flower fly genus Ornidia Lepeltier \& Serville (Diptera: Syrphidae) with the description of a new species from Brazil. Zootaxa, 2014: 59-64.

Cumming, J.M.; Wood, D.M. 2009. Adult morphology and terminology. In: Brown, B.V.; Borkent, A.; Cumming, J.M.; Wood, D.M.; Woodley, N.E.; Zumbado, M.A. (Ed.). Manual of Central American Diptera. NRC Research Press, Ottawa, Ontario, Canada, p. 9-50.

Curran, C.H. 1934. Diptera of Kartabo, Bartica District, British Guiana. Bulletin of the American Museum of Natural History, 66: 287-532.

Curran, C.H. 1939. Synopsis of the American species of Volucella (Syrphidae; Diptera). American Museum Novitates, 1027: 1-7.

Curran, C.H. 1941. New American Syrphidae. Bulletin of the American Museum of Natural History, 78: 243-304.

Curran, C.H. 1953. Notes and descriptions of some Mydaidae and Syrphidae (Diptera). American Museum Novitates, 1645: 1-15.

Dickinson, J.L.; Zuckerberg, B.; Bonter, D.N. 2010. Citizen science as an ecological research tool: Challenges and benefits. Annual Review of Ecology, Evolution and Systematics, 41: 149-172.

Doesburg, P.H.V. 1963. Preliminary list of Syrphidae known from Suriname and British and French Guiana. Studies on the fauna of Suriname and other Guyanas, 5: 1-33.

Doesburg, P.H.V. 1966. Syrphidae from Suriname. Additional records and descriptions. Studies on the fauna of Suriname and other Guyanas, 9: 61-67.

Fearnside, P.M. 2014. Impacts of Brazil's Madeira river dams: Unlearned lessons for hydroelectric development in Amazonia. Environmental Science \& Policy, 38: 164-172.

Fluke, C.L. 1937. New South American Syrphidae (Diptera). American Museum Novitates, 941: 1-14.

Fluke, C.L. 1942. Revision of the neotropical Syrphini related to Syrphus (Diptera, Syrphidae). American Museum Novitates, 1201: 1-24.

Fluke, C.L. 1943. A new genus and a new species of Syrphidae (Diptera) from Ecuador. Annals of the Entomological Society of America, 36: 425-431.

Fluke, C.L. 1945. The Melanostomini of the neotropical region. American Museum Novitates, 1272: 1-29.

Fluke, C.L. 1951. Syrphid flies related to Volucella scutellata Macquart. American Museum Novitates, 1503: 1-24.

Hippa, H.; Thompson, F.C. 1994. Revision of the Sterphus cybele species group (Diptera: Syrphidae). Proceedings of the Entomological Society of Washington, 96: 483-495.
Hoorn, C.; Wesselingh, F.P. 2010. Introduction: Amazonia, landscape and species evolution. In: Hoorn, C.; Wesselingh, F.P. (Ed.). Amazonia: Landscape and species evolution - A look into the past. Wiley-Blackwell, Oxford, United Kingdom, p. 1-8.

Hull, F.M. 1942. The flies of the genus Meromacrus. American Museum Novitates, 1200: 1-12.

Hull, F.M. 1946. The genus Lepidostola Mik. American Museum Novitates, 1326: 1-15.

Hull, F.M. 1949. The genus Baccha from the New World. Entomologica Americana, 27: 89-285.

Kassebeer, C.F. 2000. Zur gattung Pseudodoros Becker, 1903 (Diptera, Syrphidae). Dipteron, 3: 73-92.

Lagrange, E.B. 1992. Revision de las especies argentinas del grupo vinetorum del genero Palpada Macquart 1834 (Diptera, Syrphidae). Revista de la sociedad Entomologica Argentina, 50: 145-166.

Luz, F.J. de F.; de Oliveira, J.M.F. 2012. Orquídeas de Roraima. Embrapa, Brasília, 2012, 181 p.

Mengual, X. 2011. Black-tie dress code: two new species of the genus Toxomerus (Diptera, Syrphidae). Zookeys, 140: 1-26.

Mengual, X.; Thompson, F.C. 2008. A Taxonomic review of the Palpada ruficeps species group, with the description of a new flower fly from Colombia (Diptera: Syrphidae). Zootaxa, 1741: 31-36.

Mengual, X.; Ruiz, C.; Rojo, S.; Ståhls, G.; Thompson, F.C. 2009. A conspectus of the flower fly genus Allograpta (Diptera: Syrphidae) with description of a new subgenus and species. Zootaxa, 2214: $1-28$.

Mengual, X.; Thompson, F.C. 2011. Carmine cochineal killers: the flower fly genus Eosalpingogaster Hull (Diptera: Syrphidae) revised. Systematic Entomology, 36: 713-731.

Mengual, X.; Ståhls, G.; Rojo, S. 2015. Phylogenetic relationships and taxonomic ranking of pipizine flower flies (Diptera: Syrphidae) with implications for the evolution of aphidophagy. Cladistics, 31: 491-508.

Miranda, G.F.G. 2011. An overview of the genus Ocyptamus Macquart, 1834 with a revision of the Ocyptamus tristis species group. PhD thesis, University of Guelph, Guelph, Ontario, Canada. 620 p.

Miranda, G.F.G. 2014. Ceriomicrodon petiolatus Hull, 1937 (Diptera, Syrphidae, Microdontinae): Redescription and new records. Zootaxa, 3846: 584-590.

Miranda, G.F.G.; Young, A.D.; Locke, M.M.; Marshall, S.A.; Skevington, J.H.; Thompson, F.C. 2013. Key to the genera of nearctic Syrphidae. Canadian Journal of Arthropod Identification, 23. (http://www.biology.ualberta.ca/bsc/ejournal/mylmst_23/ mylmst_23.html). Accessed on 23/03/2015.

Miranda, G.F.G.; Marshall, S.A.; Skevington, J.H. 2014. Revision of the genus Pelecinobaccha Shannon, description of Relictanum gen. nov., and redescription of Atylobaccha flukiella (Curran, 1941) (Diptera: Syrphidae). Zootaxa, 3819: 1-154. 
Montoya, A.L.; Pérez, S.P.; Wolff, M. 2012. The diversity of flower flies (Diptera: Syrphidae) in Colombia and their neotropical distribution. Neotropical Entomology, 41: 46-56.

Morales, M.N.; Marinoni, L. 2009. Cladistic analysis and taxonomic revision of the scutellaris group of Palpada Macquart (Diptera: Syrphidae). Invertebrate systematics, 23: 301-347.

Owen, J. 2010. Wildlife of a Garden: A thirty-year study. Royal Horticultural Society, Londres, 2010, 276 p.

Papavero, N. 1962. Quatro novas species de Microdontinae do Brasil (Diptera, Syrphidae). Papéis Avulsos do Departamento de Zoologia, 15: 317-326.

Pérez-Lachaud, G.; Jervis, M.A.; Reemer, M.; Lachaud, J.-P. 2014. An unusual, but not unexpected, evolutionary step taken by syrphid flies: the first record of true parasitoidism of ants by Microdontinae. Biological Journal of the Linnean Society, 111: 462-472.

Quaresma, H.D. de A.B. 2003. O desencanto da princesa: pescadores tradicionais e turismo de proteção ambiental de Algodoal/ Maiandeua. NAEA, Belém, 2003, 254 p.

Rafael, J.A.; Aguiar, A.P.; Amorim, D.S. 2009. Insect diversity in Brazil: Challenges and advances. Neotropical Entomology, 38: 565-570.

Reemer, M. 2008. Surimyia, a new genus of Microdontinae, with notes on Paragodon Thompson, 1969 (Diptera, Syrphidae). Zoölogische Mededelingen, 82: 177-188.

Reemer, M. 2010. A second survey of Surinam Syrphidae (Diptera): Introduction and Syrphinae. Tijdschrift voor Entomologie, 153: 163-196.

Reemer, M. 2012. Unravelling a hotchpotch: phylogeny and classification of the Microdontinae (Diptera: Syrphidae). Tese de doutorado, Leiden University, Leida, Holanda do Sul, Holanda. 384 p.

Reemer, M. 2013. Taxonomic exploration of Neotropical Microdontinae (Diptera: Syrphidae) mimicking stingless bees. Zootaxa, 3697: 1-88.

Reemer, M. 2014. A review of the Microdontinae (Diptera: Syrphidae) of Surinam, with a key to the Neotropical genera. Tijdschrift voor Entomologie, 157: 27-57.

Reemer, M.; Ståhls, G. 2013a. Generic revision and species classification of the Microdontinae (Diptera, Syrphidae). Zookeys, 288: 1-213.

Reemer, M; Ståhls, G. 2013b. Phylogenetic relationships of Microdontinae (Diptera: Syrphidae) based on molecular and morphological characters. Systematic Entomology, 38: 661-688.

Ricarte, A.; Marcos-García, M.A.; Hancock, G.; Rotheray, G.E. 2012. Revision of the new world genus Quichuana Knab, 1913 (Diptera: Syrphidae), including descriptions of 24 new species. Zoological Journal of the Linnean Society, 166: 72-131.

Rotheray, G.E.; Gilbert, F. 1999. Phylogeny of palaearctic Syrphidae (Diptera): evidence from larval stages. Zoological Journal of the Linnean Society, 127: 1-112.
Rotheray, G.E.; Zumbado, M.; Hancock, E.G.; Thompson, F.C. 2000. Remarkable aquatic predators in the genus Ocyptamus (Diptera, Syrphidae). Studia Dipterologica, 7: 385-398.

Rotheray, G.E.; Hancock, E.G.; Marcos-García, M.A. 2007. Neotropical Copestylum (Diptera, Syrphidae) breeding in bromeliads (Bromeliaceae) including 22 new species. Zoological Journal of the Linnean Society, 150: 267-317.

Sigrist, T. 2012. Mamíferos do Brasil - Uma visão artística. Avis Brasilis, Vinhedo, 2012, 448 p.

Thompson, F.C. 1968. The placement of the subgenus Protolepidostola Hull (Diptera: Syrphidae) with description of two new species. Journal of the Kansas Entomological Society, 41: 270-277.

Thompson, F.C. 1981. The flower flies of the West Indies (Diptera: Syrphidae). Memories of the Entomological Society of Washington, 9: $1-200$.

Thompson, F.C. 1999. A key to the genera of the flower flies (Diptera: Syrphidae) of the neotropical region including descriptions of new genera and species and a glossary of taxonomic terms. Contributions on Entomology, International, 3: 321-378.

Thompson, F.C. 2007a. A new Costa Rican flower fly (Diptera: Syrphidae) and a replacement name for a neotropical flower fly genus. Studia Dipterologica, 14: 167-170.

Thompson, F.C. 2007b. Microdon falcatus Williston (Diptera: Syrphidae): A redescription, with lectotype designation and new synonyms. Entomological News, 118: 283-291.

Thompson, F.C. 2010. Syrphidae. Systema dipterorum. (http://www. diptera.org/). Accessed on 01/05/2014.

Thompson, F.C. 2012. Fabulous flower flies for famous fly fanatics (Diptera: Syrphidae). A tribute to the dipterists of the Canadian National Collection. Canadian Entomologist, 144: 1-16.

Thompson, F.C.; Vockeroth, J.R.; Sedman, Y.S. 1976. 46 Family Syrphidae. In: Papavero, N. (Ed.). A catalogue of the Diptera of the Americas south of the United States. Edanee. São Paulo, São Paulo, p. 1-195.

Thompson, F.C.; Zumbado, M.A. 2000. Flower flies of the subgenus Ocyptamus (Mimocalla Hull) (Diptera: Syrphidae). Proceedings of the Entomological Society of Washington, 102: 773-793.

Thompson, F.C.; Rotheray, G.E.; Zumbado, M. 2010. Syrphidae (flower flies). In: Brown, B.V.; Borkent, A.; Cumming, J.M.; Wood, D.M.; Woodley, N.E.; Zumbado, M.A. (Ed.). Manual of Central American Diptera. NRC Research press, Ottawa, Ontario, Canada, p. 763-792.

Vockeroth, J.R. 1964. The genus Alipumilio Shannon (Diptera: Syrphidae). Canadian Entomologist, 96: 922-924.

Vockeroth, J.R. 1969. A revision of the genera of the Syrphini (Diptera: Syrphidae). Memories of the Entomological Society of Canada, 62: 1-176.

Zumbado, M.A.; Thompson, F.C. 1997. Nuevas species de Sterphus (Diptera: Syrphidae) de Costa Rica con notas sobre otras especies presentes en Costa Rica. Southwestern Entomologist, 22: 79-90.

Received: 19/04/2016

Accepted: 27/06/2016 
Appendix 1. Transcription of locality labels from the specimens representing new records of Syrphidae. 'GFGM' are codes from the author's personal database; ' represents a new line in the locality label.

Aristosyrphus (Aristosyrphus) sp.

1 female, "BRASIL, Amazonas, / Borba, Rio Abacaxis / 0515’09”S - 5841'52”W” “35m. 27-29.v.2008. J.A. / Rafael e equipe. Malaise" "INPA-DIP0000036" (INPA)

1 female, "BRA, Amazonas, Reserva / Florestal Adolpho Ducke / Igarapé Uberê. Malaise / xii.2002" "J.M.F.Ribeiro, Jo. Vidal \& Ja / Vidal" "INPA-DIP0000068" (INPA)

1 female, "BRA, Amazonas, Reserva / Florestal Adolpho Ducke / 23.ix.1986 / L. Ulysses" “INPA-DIP000065” (INPA)

Calostigma elnora Shannon, 1927

1 female, "BRASIL, AM, Maués, Rio / Abacaxis, Campina / Pacamiri, 0435'49”S-" “58¹3'14”W, 30-31.v.2008 / J.A.Rafael e equipe, arm / susp dossel mata" "INPADIP000173" (INPA)

Carreramyia sp.

1 female, "BRA, Amazonas, Manaus / Reserva Adolpho Ducke, / 255'29”S 5959'19”W. / 30.iii-04.iv.2012. / Malaise suspensa"”PPGEnt-INPA. 2012." “INPA-DIP000001" (INPA)

1 female, "BRASIL: Amazonas / 26km NE Manaus / Reserva Ducke / 7-xii-1988" "J.A.Rafael / Arm. Suspensa / 20 metros" "0019493" (INPA)

1 female, "BRA, Amazonas, Novo / Aripuana, Guariuba, Rio / Aripuana. Armadilha suspensa / 15m em terra firme. 18- / 24.viii.1999. / J.F.Vidal \& A.L.Henriques" "INPADIP000002" (INPA)

Cepa margarita (Thompson, 1999)

1 female, "BRA, Amazonas, Fazenda / Esteio, Km41 (Res.1501). / 02 25'S-59 52'W. Suspensa 6. / 15-25.x.1995” "Projeto Dinâmica Biológica de Fragmentos Florestais" "INPA-DIP00000067" (INPA)

Ceratophya carinifacies (Curran, 1934)

1 female, "Brasil (MA),C.N.Maranhão / REBIO - Res. Biol. Gurupi / 031'05"S / 46²1'83"W" "Armadilha suspensa / 01-06.iii.2011, F.Limeira-de- / Oliveira \& D.W.A.Marques" "GFGM-CZMA0003" (CZMA)

Domodon zodiacus Reemer, 2013

1 male, "BRASIL, Amazonas / S. Gabriel Cachoeira / Morro 6 lagos / 28.ix-6.x.199” "300m / Arm. Malaise / J.A. Rejael / J. Vidal” "INPA-DIP0000035” (INPA)

Eosalpingogaster cochenillivora (Guérin-Méneville, 1848)

1 male, "Brasil Pará / Serra Norte / N1.C rupestre / 20.vi.1985" "Brasil Pará / M.F. Torres" "MPEGDIP12170472” (MPEG)
Hybobathus placivus (Williston, 1888)

1 male, "Brasil Pará / Benevides Faz. / Morelandia / 6.VII.1988" "Brasil Pará / J. Dias" "GFGM-MPEG0006" (MPEG)

Hypselosyrphus trigonus Hull, 1937

1 female, "BRASIL. AM, Barcelos, Rio / Aracá, boca rio Curuduri / $00^{\circ} 05^{\prime} 50.2^{\prime} \mathrm{N} 63^{\circ} 17^{\prime} 22.3^{\prime} \mathrm{W} /$ 15-19.vi.2010, suspensa / dossel, 35m, E. Alvim, J.A. / Rafael, R. Freitas Silva"'INPA-DIP0000007" (INPA)

Mallota sp.

2 females, "Brasil, Amazonas / S. Gabriel da Cachoeira / Serra da Neblina / Lajero. 1780m / -65.982/0,808 / 24.viii.2005 R.L. Dias" "INPA-DIP0000760 \& ...761" (INPA)

Masarygus planifrons Brèthes, 1908

1 male, "Brasil Pará / Benevides Faz. / Morelandia / 29.VI.1988" "Brasil Pará / F.F. Ramos" "GFGM-MPEG0005" (MPEG)

Menidon falcatus (Williston, 1887)

1 female, "BRASIL, AM, Resex Unini / Rio Unini, lago 03 bocas / 0134'13"S, 62 58'54"W / 14-28.vii.2004” "Arm. Suspensa 25m / M.L.Oliveira, A. Silva F. / L. Aquino leg." "INPA-DIP0000046" (INPA)

Meromacrus milesia Hull, 1942

1 female, "TEFÉ / Amazonas, Brasil / VIII.1959 / R. Carvalho" (MNRJ)

1 female, "TEFÉ / Amazonas, Brasil / XI.1959 / R. Carvalho" (MNRJ)

M. pachypus (Wiedemann, 1830)

1 female, "TEFÉ / Amazonas, Brasil / XII.1959 / R. Carvalho" (MNRJ)

Microdon (Microdon) macquartii Lynch-Arribalzaga, 1891

1 female, "BRA, Amazonas / Manaus, Res. Ducke / Igarapé Tinga / Arm. Suspensa 20m" "6-16.xii.2004 / Henriques, A. Leg." "INPA-DIP000754" (INPA)

Nausigaster bonariensis Lynch-Arribalzaga, 1892

1 female, "Brasil, Pará Monte Alegre / 16 a 20.I. 1992 / A. L. Henriques" "Armadilha / Cerrado / Malayse" "Brasil, Pará / O.T. Silveira" "GFGM-MPEG 0010" (MPEG)

Ocyptamus icarus Reemer, 2010

1 male, "Brasil, AC - Rio Branco / 25.X a 8.XI-91 / F.Ramos / A. Henriques / I. Gorayeb / N. Bittencourt" "Mata / Terra Firme" "GFGM-MPEG0003” (MPEG) 


\section{O. obliquus (Curran, 1941)}

1 female, "BRASIL, Amazonas / Barcelos, viii.2008 / Bacuquara / 009'09"N; 6310'38”W" "Coleta Manual / A. Silva \& R. Machado" "INPA-DIP0000248” (INPA)

3 males, "BRASIL, Amazonas / Barcelos, viii.2008 / Bacuquara / 009'09"N; 6310'38”W" "Coleta Manual / A. Silva \& R. Machado" (INPA)

1 female, "BRA, Amazonas, Manaus, Rio / Solimões $S$ 0130'205” / W 061³1'975”. Tenda do / barco, 8:45h. L. Salvatierra" "INPA-DIP0000251" (INPA)

\section{O. prenes (Curran, 1930)}

1 male, "BRASIL, Amazonas, Manaus, / Estação de Horticultura do INPA / 02 $59^{\prime} 46.2^{\prime \prime} S$ e $60^{\circ} 01^{\prime} 24.7^{\prime \prime} \mathrm{W}$ 18.ii.2007 - Colleto- / Silva,A. catação / coletado no camucamu" "INPA-DIP0000246" (INPA)

1 female, "BRASIL, Amazonas, Manaus, / Estação de Horticultura do INPA / 02 $59^{\circ} 46.2^{\prime \prime} \mathrm{S}$ e $60^{\circ} 01^{\prime} 24.7$ "W / 29.x.2005 - Colleto-Silva,A. / catação no camu-camu" (INPA)

\section{Orthoneura sp.}

1 female, "BRA, Amazonas, Novo / Aripuana, Res. Soka. Malaise. / seca. $05^{\circ} 15$ '53"S-6007’08”W. / 17-25.viii.1999 / J. Vidal \& A.L. Henriques"'INPA-DIP0000185" (INPA)

2 females, "Brasil(MA), São P. Água / Branca, Faz. Esplanada, / Arm. Malaise, 10-16.ix. / 2001, F. Limeira-deOli- / veira\& J.T. Câmara" (CZMA)

Palpada aemula (Williston, 1891)

1 female, "BRASIL, Pará, Rio / Nhamundá, / $01^{\circ} 35^{\prime} 11^{\prime}$ S - 57³7’32”W” “25m. 17-20.v.2008. J.A. / Rafael e equipe. Malaise" (INPA)

\section{P. agrorum (Fabricius, 1787)}

1 male and 1 female, "BRASIL, AM, Rio Solimóes, Lago do José, / Prox. Manaus. 09.viii" "1979. J Adis e equipe. Fumigação (fogging)" (INPA)

1 male, "BRASIL, Amazonas / Manaus / Tarumã baixa / 300'17” 6002'20” "25.Fev.1982 / B.W.Nelson \& / G.T. Prance leg. / Rhabdodendrum macrophylum" (INPA)

1 female, "BRASIL AM, Benjamin / Constant, Ig. Crajarizinho / 042635S-695958W / 08-10.ix.2005, Malaise, / J.A.Rafael \& F.F.Xavier Fo" (INPA)

1 female, "BRASIL. Amazonas / Serra do Aracá 1073 m.a. / 00 $53^{\prime} 44.2^{\prime \prime} \mathrm{N} / 63^{\circ} 26^{\prime} 15.9^{\prime \prime} \mathrm{W} /$ 02-08.viii.2007. coleta manual / M.L.Oliveira \& A.S.Filho leg” (INPA)

1 female, "BRASIL Amazonas / Barcelos, vii.2007 / Serra do Aracá, 1.100m / 054’35”N; 6326’01"W" "Na luz / A. Filho leg." (INPA)

\section{P. fasciata (Wiedemann, 1819)}

1 male, "BRASIL. Amazonas / Serra do Aracá 1073 m.a. / 00 $53^{\prime} 44.2^{\prime \prime} \mathrm{N} / 63^{\circ} 26^{\prime} 15.9^{\prime \prime} \mathrm{W} /$ 02-08.viii.2007. coleta manual / M.L.Oliveira \& A.S.Filho leg" (INPA)

1 female, "BRASIL Amazonas / Barcelos, vii.2007 / Serra do Aracá, $1.100 \mathrm{~m} / 0^{\circ} 54^{\prime} 35^{\prime} \mathrm{N}$; 6326’01"W" "Na luz / A. Filho leg." (INPA)

1 female, "BRA, Amazonas, Novo / Aripuanã, lago Xadá / 0515’39"S 6042’32”W / iv.2005" "Armadilha Malaise / F. Xavier, F. Godoi / \& A. Lourido leg." (INPA)

1 female, "BRASIL, Amazonas, Manaus / Estação Exper. Silvicultura / Tropical, BR-174, km43 / 24.iv.2003" "Rede entomológica / Floresta / Galinkin J.” (INPA)

1 female, "BRASIL. Pará, Anapú, / Rod. Transamazônica rio / São José, 50 m” “03²4’18”S-51¹6’37”W / 06.iv.2008, arm. Luz / J.A.Rafael, F.F.Xavier Fo" (INPA)

\section{Pelecinobaccha pandora (Hull, 1941)}

1 female, "Brasil AC - Rio Branco / 25 - X a 8 - XI - 91 / F. Ramos / A. Henriques / I. Gorayeb / N. Bittencourt" "Armadilha / Malayse / T. Firme" "GFGM-MPEG0001" (MPEG)

Polybiomyia bigotii (Williston, 1888)

1 male, "BRASIL, RR, Amajari, Serra / Tepequém 034” 35.5”N - / 61\%43’39”W, 10-12.vii.2010 / J.A.Rafael varredura" "INPA-DIP0000175" (INPA)

\section{Pseudomicrodon polistoides Reemer, 2013}

1 female, "BRASIL, Amazonas / Carauari, 505'31"S / 67¹0’03". Vii.2005 / Luz mista/mercúrio" "A. Henriques \& Xavier-Filho leg." "INPA-DIP0000075” (INPA)

P. smiti Reemer, 2013

1 female, "BRA, Amazonas, Manaus, / Campus Universitário-UFAM / Malaise, 19.v.1979 / J.A.Rafael” "INPA-DIP0000073" (INPA)

1 male, "BRASIL, AM, Resex Unini / Rio Unini, lago 03 bocas / 01³4'13”S, 6258'54”W / 14-28.vii.2004” “Arm. Suspensa lâmina / d'água, M.L.Oliveira, / A. Silva F. L. Aquino leg." "INPA-DIP0000075" (INPA)

Quichuana longicauda Ricarte \& Hancock, 2012

1 female, "BRASIL, AM, Borba, Rio / Abacaxis, Paxiúba / 0428'48”S-59²9'34”W” “02-04.vi.2008, J.A.Rafael / e equipe, arm. Suspensa / 30mts." (INPA)

Schizoceratomyia barretoi Carrera, Lopes \& Lane, 1947

1 male, "Caimbé Vigia / 24.II.1968" "Brasil PA / J. Barata” (MPEG)

1 male, "Caimbé Vigia / 24.II.1968" "Brasil PA / T. Pimentel” (MPEG)

1 female, "Caimbé Vigia / 24.II.1968" "Brasil PA / T. Pimentel” "GFM-MPEG0008” (MPEG) 
Stipomorpha apicula (Curran, 1930)

4 males and 6 females, "BRA, Amazonas, Manaus, I Campus Universitário-UFAM/ [several dates] / J.A.Rafael" "INPA-DIP0000015-24" (INPA)

S. goettei (Shannon, 1927)

1 male, "BRASIL, AM, Ipixuna, Rio / Liberdade, Estirão da Preta / 07²1'46.7”S - 7152'07.1”W / 11-15.v.2011. Arm. Malaise" "J.A.Rafael, J.T.Câmara, R.F. / Silva, A. Somavilla, C. / Gonçalves, leg." "INPA-DIP0000011” (INPA)

S. guianica (Curran, 1925)

1 female, "BRASIL, AM, Resex Unini / Rio Unini, lago 03 bocas / 01³4'13”S, 6258'54”W / 14-28.vii.2004” “Arm. Suspensa em Igarapé / M.L.Oliveira, A. Silva F. / L. Aquino leg." "INPA-DIP0000012" (INPA)

S. mackiei (Shannon, 1927)

1 male, "BRASIL, AM, Resex Unini / Rio Unini, lago 03 bocas / 01³4'13”S, 6258'54”W / 14-28.vii.2004” “Arm. Suspensa lâmina / d'água, M.L.Oliveira, / A. Silva F. L. Aquino leg." "INPA-DIP0000025" (INPA)

Surimyia minutula (Doesburg, 1966)

1 male, "BRA, Amazonas, Parque / Nacional do Jaú, Seringalzinho / (Nazaré), right margin rio Jaú, / 37m. Asl PNJ018. 01 ${ }^{\circ} 54$ '45”S- / 61 35'25”W. 30.vi-06.vii.2003.” "Malaise trap (N) / Campina D.M. Takiya" "INPADIP0000088” (INPA)
Trichopsomyia polita Williston, 1888

1 female, "BRA, Roraima, Uiramutá / Rio Wailá. 0437'50”S, / 6009’46”W, 19- / 22.iii.2007. Xavier Fo, F.F. / Arm. Malaise" "INPA-DIP0000166" (INPA)

Xanthandrus plaumanni Fluke, 1937

1 female, "BRASIL, Amazonas / Barcelos, Rio Demeni / Jalauaca, viii.2008 / 0¹6'15”S, 6244'49”W” “Armadilha suspensa $25 \mathrm{~m}$ / Terra firme, floresta / A. Silva \& R. Machado" "INPA-DIP000165" (INPA)

1 male, "BRASIL, RR, Amajari, Serra / Tepequém 034” 35.5”N - / 6143'39”W, 10-12.vii.2010 / J.A.Rafael varredura" "INPA-DIP0000138" (INPA)

\section{Supplementary material}

Supplementary material 1 - Photographic identification key to the genera of Syrphidae from the Brazilian Amazon (key.pdf)

Available at: http://keys.inpa.gov.br/?idkey=syrphidae

Supplementary material 2 - Glossary of common terms (Glossary.jpeg)

Available at: http://keys.inpa.gov.br/?idkey=syrphidae

Supplementary material 3 - Orientation of specimens (Orientation.jpeg)

Available at: http://keys.inpa.gov.br/?idkey=syrphidae 